\title{
Social Responsibility At The Academic Level. Study Case: The University Of Bucharest
}

\author{
Paul Marinescu, University of Bucharest, Romania \\ Sorin-George Toma, University of Bucharest, Romania \\ Ionuț Constantin, University of Bucharest, Romania
}

\begin{abstract}
In the last decades the corporate social responsibility (CSR) has been a major subject both for universities, civil society and businesses. Although the CSR concept is especially promoted by large multinational and transnational corporations, it has become also a prominent issue for universities. Social responsibility represents more than a challenge for universities. It has to be a purpose of the universities, taking into account that young people formation also means creating a high level of awareness about the need to involve members of society in solving social problems. Our paper contributes for better clarifying the CSR concept and presents as a study case some of initiatives of the University of Bucharest related to the social responsibility.
\end{abstract}

\section{Keywords}

corporate social responsibility, university, social responsibility, Team Work Association, University of Bucharest, Faculty of Administration and Business

\section{JEL Codes: M 14, I 21}

\section{Introduction}

A global phenomenon, the corporate social responsibility (CSR) aims to solve economic, social and environmental problems in order to increase both the benefits for society and for the companies. On the other hand, the CSR aims to educate people to become fully engaged actors in the change of society they live.

Education in general and higher education in particular, teaches people how to respond to the postmodern society challenges abiding by legal constraints and ethical principles, how to accomplish tasks to society and how to be responsible global citizens. Helping people become more socially responsible represents an essential objective for today's universities (Giancalone, Thompson, 2006). In this respect every student's/graduate's attitude has to be centered on the ultimate goal of acting only with complete social responsibility (Sawasdikosol, 2009).

As the universities have become more socially engaged their role in society has fundamentally changed. They accept "their public responsibility for promoting social equity and an inclusive society" (EUA, 2007, p. 2).

The paper contributes for better clarifying the CSR concept and presents as a study case some of initiatives of the University of Bucharest related to social responsibility. Our paper is structured as follows: in the first section, we analyse the CSR concept and its relationship with businesses and universities. In the second section we show how the Team Work Association and the scientific circle "Business, ethics and social responsibility" have implemented social responsibility projects within the University of Bucharest and in partnership with other institutions. Finally some conclusions are presented. 


\section{From the social responsibility of corporations to the social responsibility of universities}

In the last decades the CSR has become a major subject both for universities, civil society and businesses. Corporate Sustainability, Corporate Citizenship and Socially Responsible Behaviour are other terms which have been used more or less as synonyms in the literature. Since the end of the Second World War, academics and practitioners have tried to establish an agreed-upon definition of the CSR concept. In the last decade these definitions have pointed out that CSR is a global concept (Table 1).

Table 1- Definitions of CSR

\begin{tabular}{|l|l|l|}
\hline No. & Author, year & Definition \\
\hline 1. & $\begin{array}{l}\text { Kotler P., Lee N. } \\
(2005)\end{array}$ & $\begin{array}{l}\text { CSR is "a commitment to improve community well- } \\
\text { being through discretionary business practices and } \\
\text { contributions of corporate resources". }\end{array}$ \\
\hline 2. & $\begin{array}{l}\text { World Business } \\
\text { Council for } \\
\text { Sustainable } \\
\text { Development } \\
\text { (2004) }\end{array}$ & $\begin{array}{l}\text { CSR describes "business' commitment to contribute } \\
\text { to sustainable economic development, working with } \\
\text { employees, their families, the local community, and } \\
\text { society at large to improve their quality of life". }\end{array}$ \\
\hline 3. & $\begin{array}{l}\text { McWilliams A., } \\
\text { Siegel D. (2001) }\end{array}$ & $\begin{array}{l}\text { CSR is "a set of actions that appear to further some } \\
\text { social good, beyond the interests of the firm and that } \\
\text { which is requiring by law". }\end{array}$ \\
\hline 4. & $\begin{array}{l}\text { European } \\
\text { Commission- Green } \\
\text { Paper (2001) }\end{array}$ & $\begin{array}{l}\text { CSR is "a concept whereby companies decide } \\
\text { voluntarily to contribute to a better society and a } \\
\text { cleaner environment". }\end{array}$ \\
\hline 5. & $\begin{array}{l}\text { Dessler G. (2001) } \\
\text { CSR refers to the extent to which companies should } \\
\text { and do channel resources toward improving one or } \\
\text { more segments of society other than the firm's own } \\
\text { stockholders. }\end{array}$ \\
\hline
\end{tabular}

The above mentioned definitions show that they are to a large degree congruent. In essence the CSR:

- constitutes an inclusive concept, embracing the entire spectrum of socially and environmentally beneficial activities of businesses;

- $\quad$ is an eclectic and multidisciplinary field broadly focused (Carroll, 1994);

- combines the contribution to economic prosperity with environmental quality and social capital;

- honors ethical values and respects people, communities, and the natural environment (White, 2006);

- represents an interactive and continuous improvement process, including internal (e.g. employees) and external (e.g. shareholders) stakeholders;

- imposes the company to behave not only efficiently, but also environmentally and socially responsible;

- is treated rather as an investment, not a cost, and is linked to profitability;

- comprises four components (Carroll, 1991): economic, legal, ethical and philanthropic (Figure 1). 


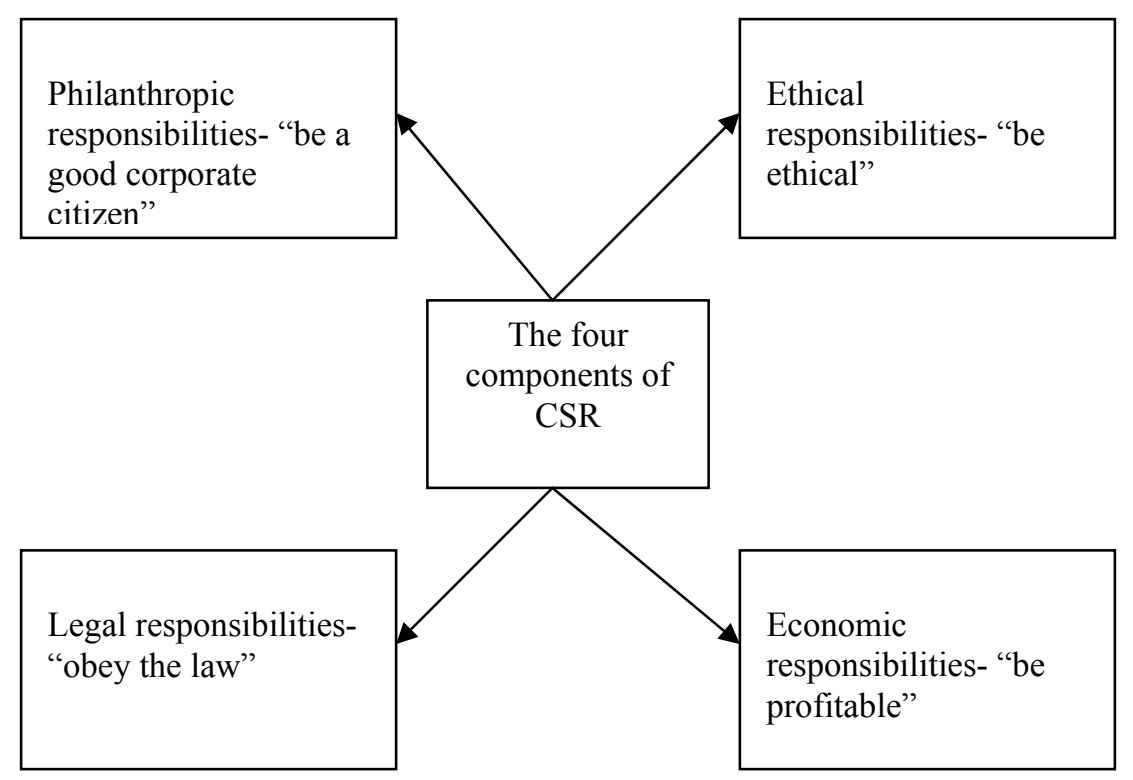

Figure 1- The four components of CSR

The CSR concept is important in the business world because consumers want to buy products and/or services form companies they trust. Therefore, CSR represents today a crucial element to maintaining success in business. Due to several factors as globalization, changing social expectations or increasing affluence, more and more organizations are interested in social responsibility.

Although the CSR is especially promoted by large multinational and transnational corporations, it has become also a prominent issue for universities. There are several reasons that explain the application of CSR towards universities as follows:

- universities are the main contributors for the formation of forthcoming employees both in public and private companies;

- universities play a major educational and research role within the communities in which companies operate;

- universities help people to find a balance between their personal needs and wants and those of the society;

- as the higher education market changes, building deeper strategic relationships with their stakeholders (e.g. the students, the employers, the state, the society etc.) has become central to the competitiveness of universities;

- universities contribute to regional lifelong learning and employability;

- the corporate involvement in universities has increased due to the broader marketization of higher education services;

- the rising of the collective awareness of students and professors creates the need for implementing initiatives related to CSR;

- universities are called to play an important role in meeting the environmental challenges by integrating the sustainability concept in the curricula etc.

All these emphasize that by their contribution to the prosperity of the society universities have an increasing social responsibility. This is why universities play a critical role in creating responsible global citizens in the postmodern world. In this respect the University of Bucharest represents a valuable example. 


\section{The social responsibility of a Romanian university. Study case: University of Bucharest}

Social responsibility in academic environment represents more than a challenge. It must become a purpose of the academic environment, taking into account that young people formation also means creating a high level of awareness about the need to involve members of society in solving social problems. Identifying these problems and their resolution means attitude, effort and competence. The creation of this state may be in an organized setting in which students, teachers and practitioners can find solutions to serious social problems existing in society.

In this paper we consider the presentation of two initiatives at the University of Bucharest, in which students actively participate in solving specific problems of disadvantaged social groups. These initiatives have been translated into the achievement of a scientific circle and a professional association - Team Work.

Because on the university level we cannot separate the quality of a process from the moral actions through which it materializes, it was created the scientific circle "Business, ethics and social responsibility" of the Faculty of Administration and Business (FAA), which contains two directions of development. Within the business component it was founded a business incubator through the ideas of students, teachers and researchers can become businesses after a process of evaluation of their usefulness. Market research will demonstrate if the selected idea can become a product or service attractive for the market. If it is possible that the idea will materialize it appears the necessity of registering this idea at OSIM to become a trademark. We can speak of a laborious process in which we use the concepts of management, marketing, public relations, advertising, entrepreneurship, organizational and individual behavior, sociology, communication, commercial law.

In this coherent mixture of research are involved specialists from the domains above mentioned so the result will be of great accuracy. In achieving this scientific circle we start from the principle that successful businesses mean morality, but also social involvement. Therefore, the other components of the system created in the framework of scientific circle refer to ethics and social responsibility. "Doing the right thing" becomes a way of action in the businesses but also within the social actions. We cannot separate this kind of sets of values which we apply in the two areas. Ethics and morality are thus normal components of a common operating model in business but also in the social involvement.

In October 2009, the FAA, University of Bucharest and the School of Arts and Crafts (SAM) no. 3 Bucharest had become partners in the national project "We are not indifferent, we are your friends", which runs from 2009-2013. SAM no. 3 is a special school, where more than 600 poor youth with disabilities aged between 14-22 years study. Among the objectives of the project it counts:

- to provide help to the pupils from SAM no.3;

- to carry out pedagogical activities by the students of FAA for the pupils of SAM no. 3;

- to participate in social and sport activities etc..

In December 2009, university teachers and students donated 42 food packages, each worth 100 lei, during the Christmas holidays. At the end of March 2010, teachers and university students participated in the commissions of the contest organized by SAM no. 3. On this occasion they again donated 46 food packages, each worth more than 85 lei. This national project has become part of the activities that have been developed within the scientific circle "Business, ethics and social responsibility."

In the age of globalization it emerges a close relationship between companies, communities, and local, national and international institutions. University becomes a bridge between these entities. From the perspective of the ethical principles creating a complex of behavior skills, values and beliefs about what is and what is not morally correct is the mission of education. This is why ethics and social responsibility can be an answer to the challenges that are rising from the current economic crisis. Activities of the scientific circle and the association have 
shown us that among the major causes of the current crisis, we mention the lack of ethics in business firms and non-involvement in social action.

Since 2002, the Team Work Association has developed its actions within the University of Bucharest. It appreciates basic values as professionalism, teamwork and volunteerism. The objectives of the association are to:

- promote among students a positive attitude towards volunteering and teamwork;

- familiarize students with diverse organizational environments by carrying out projects;

- valuate the theoretical knowledge of students.

Team Work is based on the organizing principle of a company, comprising departments coordinated and composed of students, each one with its own projects in progress: Human resources- Communication- Research- International relations- Training- Team Work School.

The association's mission is to enable students to gain through volunteering, the experience needed effective employment in the labor market, offering students the opportunity to put into practice the theory taught in college. In all projects we have in our view to respect the basic principles of business ethics and social responsibility. Permanent consultation among the association members, guidance through mentoring, support through tutorials help to maximize the potential of each student. The facilitation of a participatory and active training contributes to support students in presenting problems, solving projects, and changing mentalities. Projects, debates, team work are ways to stimulate interest for real problems and to generate the needed competences to solve them.

Within the association there is an existential path: to know - to do - to be. In the framework of events realized in 2009 more than 4,000 young persons had participated.

In the School Team Work department, which has the motto "to form us by forming the others", students develop activities to help children from poor families or children without families. Their skills (mathematics, Romanian language, informatics, foreign languages etc.) are important elements in children's education. This is why the action is a way to take responsibility, but also for assessing the values of ethics and social responsibility.

The development of youth, extensive training programs and partnerships are so many opportunities to check virtues that social responsibility in finding real solutions for the social groups. The partnership with day care centers and orphanages allow Team Work association to address several students and a greater number of children.

Through Team Work School students have the opportunity to share their knowledge of young children from families with financial and social situations more difficult. Thus, the association becomes a laboratory in which are built new partnerships, where are clearly define and apply principles of ethics and social responsibility in economic, academic, and social activities.

Setting up branches in Cluj-Napoca and Craiova and developing projects in these centers are important objectives of the Team Work Association.

The activities carried out under the "The Botanic Garden - the garden of my town" program have involved more than 800 students. The projects of the program have facilitated the acquiring of essential skills in human relationships by the students involved. The environmental issues, the problems related to organization, the best use of resources imposed to find solutions at the project teams' level. The leadership proved to be the essential element in completing the projects coordinated by Team Work. Thus, the Team Work members learned how to run a system (project / team / organization).

Within the department Open Amphitheatre were held meetings with representatives of business environment, personalities of cultural life, and participants to social projects. All these experiences have shown that participants' involvement is an essential spring social activities. Youth exchanges, summer schools organized for and with youth are funded by international programs. This project enables the possibility of young people to think economically.

Writing and submitting projects, obtaining financing and implementation of a project are activities made by several students' project teams. 
Non-formal education is focused mainly on soft-skills development within training programs. The objectives of the development of these trainings are to increase students' professional potential in order to provide them employment opportunities in the labor market. Companies define another image on the graduates and can actively contribute to their training before embarking.

The national and international summer schools have contributed to the development of projects and activities that facilitate development of interpersonal and communication skills essential in running all programs of the association.

The partnerships with companies and non-governmental organizations facilitated the creation of needed competences in the business field. Research activities carried out within the research department provided answers about the educational needs of young people and suggested courses of action on integrating them into practical activities. The projects carried out within departments have pitted academic and business environments so that students, teachers and business people can build a positive relationship for both academic and business environment.

Social responsibility has become a way of action in which participants can be involved in social projects. From this inter-human relationships system the firm as an economic engine cannot be absent. Thus, we can say that the amounts allocated for social activities can educate groups about the initiative and action required as essential factors in achieving organizational performance.

The two initiatives at the University of Bucharest (the scientific circle "Business, ethics and social responsibility" and Team Work Association), demonstrate that only through active involvement of major stakeholders (e.g. students, teachers, researchers, businessmen, nongovernmental organizations) the spirit of social responsibility can live in each event.

\section{Conclusions}

Starting from the second half of the $20^{\text {th }}$ century many debates and discussion about CSR have been taking place. In the last decades the CSR has become a global concept that embraces multiple stakeholders or partners of organizations (e.g. the employees, the environment, the society). This is why there is a generalized recognition of the importance of CSR in the postmodern society.

The changing dynamic of the relationships among companies, universities and society emphasizes the need for a strong partnership among these main actors. As business cannot succeed in failing societies so do universities. Being more aware about the impact that they have upon the society within they are located the universities have fully understood the importance of their social responsibility.

\section{References}

1. Carroll A. B. (1994), The Pyramid of Corporate Social Responsibility: Toward the Moral Management of Organizational Stakeholders, Business Horizons, July/August 1991

2. Carroll A. B.(1994), Social Issues in Management Research: Expert' Views, Analysis, and Commentary, Business Society, Vol. 33(5), pp. 39-48

3. Dessler G. (2001), Management: leading people and organizations in the $21^{\text {st }}$ century, New Jersey: Prentice Hall, second edition

4. European Communities- Green Paper (2001), Promoting a European framework for corporate social responsibility, http://ec.europa.eu/employment_social/soc-dial/csr/greenpaper_en.pdf

5. European University Association, The Lisbon Declaration Europe's Universities beyond 2010: Diversity with a Common Purpose, 2007, http://www.EAU.be

6. Giancalone R. A., Thompson K. R.(2006), Business Ethics and Social Responsibility Education: Shifting the Worldview, Academy of Management Learning \& Education, 2006, Vol. 5, no. 3, pp. 266-277 


\section{Studies and Scientific Researches - Economic Edition, no. 15, 2010}

7. Kotler P., Lee N. (2005), Corporate Social Responsibility: Doing the Most Good for Your Company and Your Cause, New Jersey: John Wiley \& Sons

8. McWilliams A., Siegel D. (2001), Corporate Social Responsibility: A Theory of the Firm Perspective, Academy of Management Review, Vol. 26(1), pp. 117-127

9. Sawasdikosol S. (2009), Driving Universities' Collaboration toward the New Era of Sustainable Social Responsibility, http://www.USRAlliance.org

10. White A. L. (2006), Business Brief: Intangibles and CSR, Business for Social Responsibility, February 2006, http://www.bsr.org

11. World Business Council for Sustainable Development (2004), Corporate Social Responsibility, http://www.wbcsd.ch/templates/TemplateWBCSD 